\title{
粘着性土の浸食特性に関わる諸要因の影響 \\ EFFECT OF SOME PARAMETERS ON THE EROSION CHARACTERISTICS OF COHESIVE SEDIMENT
}

\author{
関根正人 ${ }^{1} \cdot$ 飯塚暢明 $2 \cdot$ 高部一彦 2 \\ Masato SEKINE, Nobuaki IIZUKA and Kazuhiko TAKABE \\ 1正会員 工博 早稲田大学助教授 理工学部土木工学科（ $\bar{T} 169-8555$ 東京都新宿区大久保 3-4-1) \\ 2 学生会員 早稲田大学大学院理工学研究科
}

\begin{abstract}
Erosion process of cohesive sediment was investigated experimentally in the present paper. Series of experiments were conducted systematically to clarify the effects of following three parameters, containing percentage of clay, water content ratio and flow velocity exerted on the sediment sample, on the erosion rate. The relations between the erosion rate and each parameters were evaluated. The dependence of the erosion rate on the containing percentage of clay is found to be the most interesting characteristic, the mechanism of which was explained physically.
\end{abstract}

Key Words: cohesive sediment, erosion rate, containing percentage of clay, water content ratio

\section{1. 序論}

粘着性材料の流砂機構を考える場合には, 土粒子 相互間に働く電気化学的な力が重要であり，個々の 粒子を単位として土粒子の移動を解析することが不 可能であるばかりか，移動する土塊の大きさを未知 量として取り扱わなければならなくなる。そのため, 粘着性材料の浸食機構の解明は非粘着性材料の場合 に比べて大きく立ち遅れ，1980年代までにキーとな るいくつかの研究1,2, 3,3,4)が行われたものの, 系統的な 基礎研究が不足してきた現状から，必ずしも十分な 理解が得られているとは言い難い。こうした中，近 年, 河川環境が治水・利水と並んで重要な位置を占め るに到り，粘着性材料の浸食特性に関わる速やかな る理解が望まれるようになってきた。たとえば, 河口 堰上流側に堆積したシルト・粘土からなるいわゆる ヘドロの存在は, その地点における水質を考える上 で重要であり,これを除去することが望まれるが，い かなる流速(あるいはせん断力)が作用するとこれらが 浸食されるに到るかについては確たる知見がないと いうのが現状であろう。このほか, 粘着性河岸の浸食 予測や，環境問題としての干潟やマングローブ林の
維持・保全などを考えていく上でも同じことがいえ よう.さらに, 東南アジアの河川に目を向けると, 我 が国の場合と異なり粘着性材料が主たる河道構成材 料となっている河川が数多く見られ，このような河 川では粘着性土の輸送・浸食特性に関わる知見が治 水上も極めて重要となる。こうした時代の要請を受 けて, 粘着性河岸の浸食機構に関しては, 近年急速な 研究上の進展 ${ }^{5), 6}$ が見られたが, 底泥をはじめとした 堆積粘着性土の浸食に関しては，依然としてその解 明が待たれている状況にある。

このような現状に鑑み, 筆者らは, 砂と粘土との混 合材料を「粘着性土」と名づけ, 堆積粘着性土の浸食 特性を調べる一連の実験的検討を進めてきている7),8 ,9). ある特定の粘土に限定すると, その浸食機構を支 配するパラメータとして重要なものは, 作用流速, 土 砂粒子全体に占める粘土の比率(粘土含有率), 材料に 含まれる水の粘土に対する重量比(水含有率)ならびに 締め固め度であろうと考えている。 そこで, 本研究で は, 作用流速, 粘土含有率および水含有率の違いが粘 着性土の浸食特性に及ぼす影響を明らかにすること を目的とする。なお, 本研究の位置付けは以下の通り である．前論文7),8),99では，一連の研究の第一歩とし て, 水含有率を一定として粘土含有率を变化させた 
実験の結果を中心として, 浸食が進行していくプロ セスを明確にするとともに，粘土含有率と浸食限界 流速あるいは浸食速度との関係についても簡単に報 告した. 本論文では, その後引き続き行われた実験結 果を整理し，浸食速度に関するより信頼性の高い関 係を導き出すとともに，この関係についての微視的 かつ力学的な解釈を与えている.さらに,これまで未 着手であった水含有率の違いによる浸食機構への影 響についても，その最新の検討結果を報告している.

\section{2. 実験概要}

\section{(1) 実験装置}

実験は循環式矩形断面管水路を用いて行った，水 路部は, 長さ $4 \mathrm{~m} \times$ 幅 $10 \mathrm{~cm} \times$ 高さ $10 \mathrm{~cm}$ の正方形断 面を持つ透明アクリル製で，通水中の供試体の状態 を目視にて確認できるようになっている．水路上流 端から $2 \mathrm{~m}$ の位置から下流端側に長さ $50 \mathrm{~cm} \times$ 幅 10 $\mathrm{cm} \times$ 高さ $3 \mathrm{~cm}$ の大きさの凹部が設けてあり,ここを 試験区間として浸食実験で用いる供試体を設置する ような構造になっている。また,アクリル製管路部の 上面および底面には高さ $3 \mathrm{~mm}$ のピラミッド型の粗度 が密についたゴム板が貼られており，上下面からの 境界層が十分に発達するようになっている。

\section{（2）供試体としての粘着性材料}

本研究では, 砂と粘土との混合材料である粘着性 材料を対象としており, 砂としては 3 号硅砂を, 粘土 としてはS.A.クレー(関東ベントナイト鉱業(株))をそ れぞれ使用することにした。ここで粘土として用い たS.A.クレーは，シルトと粘土との境を跨ぐような 粒度分布を持ち，一般に粘土として用いられること の多いベントナイトやカオリナイトに比べてその粘 着性が弱い. そのため, 粘着力そのものは小さくて も，この粘土の含有率のわずかな変化によっても混 合材料の耐浸食力に大きな変化が現れることが予想 されること,および, 実験材料として取り扱いが容易 であること，などの点を考慮して，この材料を用いる ことにした. 参考までに, S.A.クレーの鉱物組成はパ イロフィライトとカオリナイトから成り, 主成分は 前者であるとされる。

実験に用いる供試体の作成ならびに設置に当たっ ては次のような手順によることにした. まず, 所定の 重量比になるように計量しておいたS.A.クレー，3 号硅砂㧍よび水(ここでは水道水)を摚找器に入れ，十 分均一になるように摚找する。その後, 供試体設置区 間内に空陌が生じないように注意しながら，作成し た粘着性土を敷き詰める。供試体は，その上面がその
上下流の水路底面と同じ高さとなるように, 厚さ約 3 $\mathrm{cm}$ わたって平坦に敷き詰められ，その後，水路内を 水で満たし、て一昼夜静置し，自然平密を受けさせる。 供試体の混合比率としては, 乾燥状態の 3 号硅砂と S.A.クレーの重量和に対する後者の重量の比率(すな わち粘土含有率)を $10,20,40,60,80,90,100 \%$ とし， また，水のS.A. クレーに対する重量比率(すなわち水 含有率)を $30,40,50,60 \%$ とする．なお，供試体作成 の際に加える水に関して，その中に含まれるイオン 濃度の違いが粘着力の発現に少なからず影響するこ とが知られている.本研究では，ほぼ同じ時期に実験 が行われているため，使用した水道水はほぼ均質な 状態にあると判断しているが，この点に関しては今 後さらに検討していかなければならない.

\section{(3) 流速測定の概要}

浸食実験に先立って，供試体表面に作用するせん 断応力の評価を目的として, 流れ場についての予備 実験を行った。測定に際しては, 供試体設置区間の上 部にアクリル板を敷設し，水路底面の高さがその上 下流にわたって一定となるようにしている．流速の 測定は, 本実験で対象となる範囲の流量を通水し, 二 成分のレーザー・ドップラー流速計(ダンテック社製) を用いて行われた。その結果, 供試体設置区間に到る までに境界層の発達がほぼ完了していると判断でき ること, 側壁からそれぞれ $1 \mathrm{~cm}$ の区間を除けば流速 は横断方向に一様な鉛直分布となること，従来から 知られている矩形管路内の乱流特性と変わらない流 れが生じていること，などが確かめられた。

このような基礎的なデー夕を裏付けとして, 主流 速の鉛直分布から摩擦速度 $u^{*}$ を求め, これをせん断 力 $\tau_{0}$ に換算した值と断面平均流速との関係を調べた ところ, 抵抗係数(すなわち摩擦損失係数) $f$ が流量に よらず一定 $(=0.011)$ となるという結果が得られた。こ のことと, 本研究で用いる実験装置システムにおい て水路内の流れが流量調節のみよって制御されるこ とを考慮に入れると，供試体表面に作用する平均せ ん断力 $\bar{\tau}_{o}$ は, 流量 $Q$ の関数として

$$
\bar{\tau}_{o}=\rho f(Q / A)^{2}
$$

のように近似することができる。ここに, $A$ は水路横 断面積である。なお，側壁近傍では，この值よりも小 さなせん断力しか作用しない恐れがあるが，浸食実 験の結果から，この領域だけ浸食が緩やかに進むと いった格段の差異は見られておらず，式(1)の結果が 概ね全体の平均を表しているものと判断している. また, 浸食実験の際には, 浸食に伴い供試体表面の位 置が下方に変位するために，供試体表面に作用する 


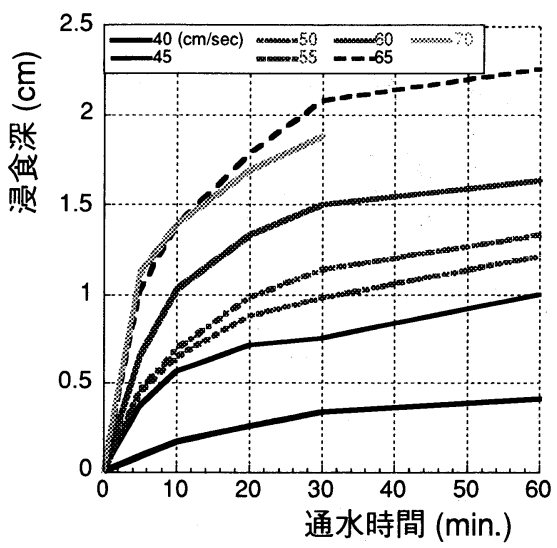

図 - 1 浸食深の経時変化： 粘土含有率 $80 \%$, 水含有率 $50 \%$
せん断力が時間とともに低下することが予想される。 そのため, 式(1)により評価されるせん断力と直接関 連づけて考えることに意味があるのは，供試体が浸 を受ける初期過程であると言えよう。

\section{(4) 浸食実験の概要}

予め準備された供試体を設置した後, 所定の流量 で通水を行い，供試体の全面にわたる浸食深を時間 を追って計測し，浸食過程の定量的な評価を行った。 供試体表面の浸食深の計測は, 原則として, 通水開始 から 5, 10, 20,30, 60 分後の各時刻において行うこと にし, 各時刻において一時通水を止め, レーザー式変 位センサーを用いて, 供試体表面上の合計 1080 点に おける表面高さを測定した. そして, これと通水前に 計測された各位置での高さとの差をとることで各位 置での浸食深を求めた. なお, 計測点数の 1080 とは, 側壁から $1 \mathrm{~cm}$ おきに流下方向に平行に設けた 9 本の 測線の各々に沿って,レーザー式変位センサーを一定 速度で移動させ, 各測線毎に120点における供試体表 面の高さを測定したことに対応している.ただし, 供 試体設置区間の上下流は固定床であるため，この区 間の上下流端から $10 \mathrm{~cm}$ 程度の範团に扔いては特異な 浸食が生じる恐れがあるため, 平均浸食深を算出す る際にはこの区間のデー夕を除外することにした。 また, 実験時には, 水路側面から供試体の溶出・浸食 状況を観察しつつ，その画像をビデオに収録すると ともに, 各時刻における浸食深の計測に先だって供 試体表面の写真撮影を行っている.

\section{3．浸食特性に及ぼす諸要因の影響評価}

\section{（1）浸食特性に及ぼす作用流速の影響}

ここでは, 粘土含有率が $80 \%$, 水含有率 $50 \%$ に設 定し, 作用流速のみを変化させて行った一連の実験 結果を例にして, 浸食機構に及ぼす作用流速(せん断

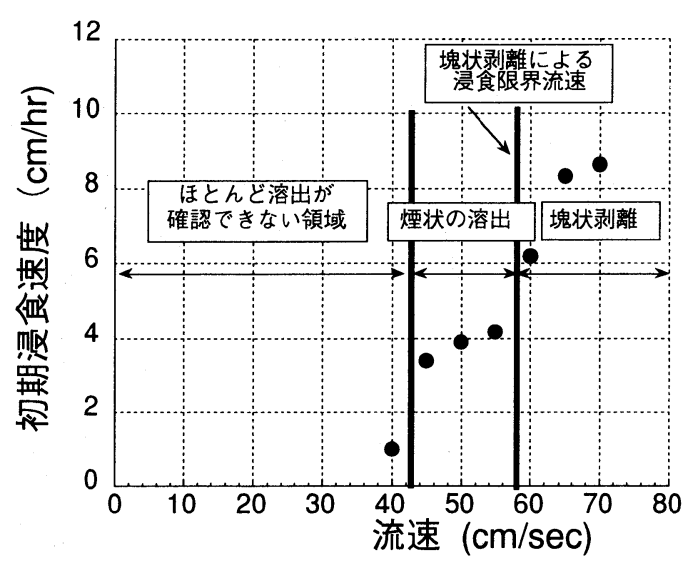

図 - 2 初期浸食速度と作用流速との関係： 粘土含有率 $80 \%$, 水含有率 $50 \%$

\section{力)の影響について説明する.}

図-1および図-2には, 浸食深の経時変化の一例と， 通水開始後 $10 \mathrm{~min}$. の浸食深から算出した初期浸食速 度と作用流速の関係をそれぞれ示している. 実験時 の観察によれば, 流速 $40 \mathrm{~cm} / \mathrm{sec}$. 以下ではほとんど浸 食が起こらず, $60 \mathrm{~cm} / \mathrm{sec}$. 以上では明らかに塊状の剥 離浸食が生じていること, 両者の中間の流速におい ては溶出形式の浸食が生じていること, などがわ かっている，図-2の結果を見てみると，この限界と なっている流速付近で浸食速度が急変していること がわかる. 本研究では, 溶出形式からこの剥離形式に 遷移する $50 \sim 60 \mathrm{~cm} / \mathrm{sec}$. を浸食限界流速と定義し，こ の限界を越える流速に対する浸食過程について主に 考えていくことにする，なお，この浸食限界流速と は, 平舘ら $)^{5}$ が浸食実験結果を整理する上で定義した ものと同義であり, 検討の結果, 本研究の範囲内では これが粘土含有率によらずほぼ一定となることがわ かった.

\section{（2）浸食特性に及ぼす粘土含有率の影響}

次に, 粘土含有率の変化に伴い生じる浸食特性の 変化について検討した結果を説明する。なおっここで は水含有率を $50 \%$ に固定して行われた一連の実験結 果を例として示す.

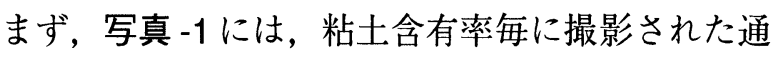
水開始から10分後の供試体表面の状況を示している. また，図-3には，浸食限界流速を越える流速である $60 \mathrm{~cm} / \mathrm{sec}$.の流れにおいて生じる浸食深の経時変化を, 粘土含有率毎に調べた結果を示している。たとえば, 粘土含有率が $80 \%$ の場合の結果について注目してみ ると, 最初の $10 \mathrm{~min}$. で約 $1 \mathrm{~cm}$ の浸食が生じ, $30 \mathrm{~min}$. ならびに $60 \mathrm{~min}$. 後には浸食深がそれぞれ $1.6 \mathrm{~cm}$ なら びに $1.8 \mathrm{~cm}$ 程度にまで及ぶことを表している。この 図より, 通水初期に急激に浸食が進んだ後, 時間の経 過とともに浸食速度が明らかに低下していくことが 

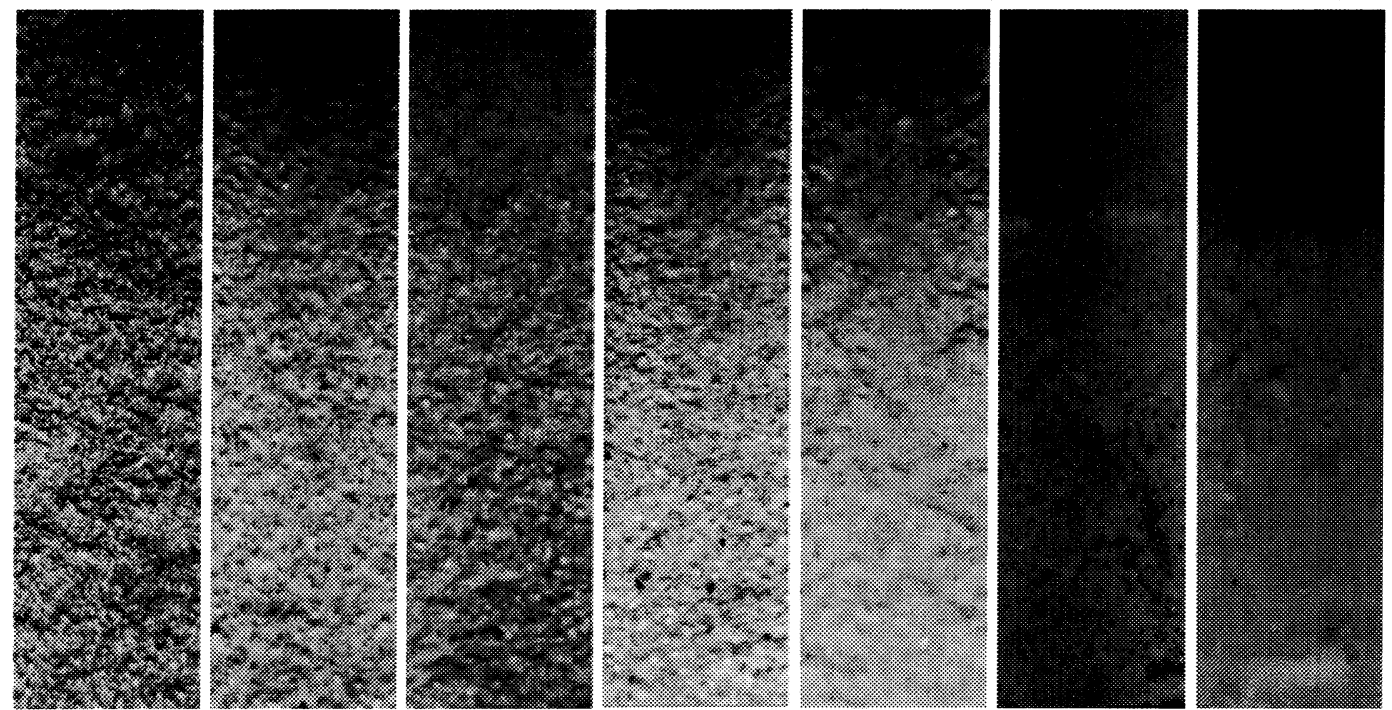

写真 - 1 通水開始から 10 分後の供試体表面の写真：粘土含有率は左から $10,20,40,60,80,90,100 \%$

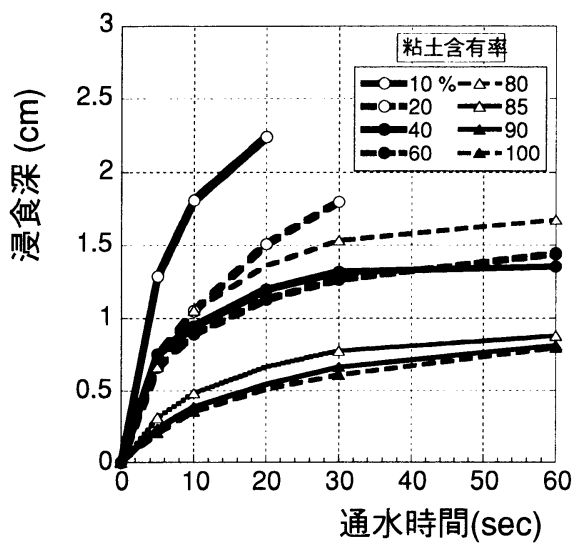

図 - 3 粘土含有率毎の浸食深の経時変化： 作用流速 $60 \mathrm{~cm} / \mathrm{sec}$, 水含有率 $50 \%$

わかる.これは,ここで用いた実験装置が, 供試体が 浸食を受けてもその上面が一定の位置にくるような 構造になっていないことに関係するもので，浸食を 受けるにつれて供試体設置区間の横断面積が増加し， 結果として作用流速が低下することが最大の原因で はないかと考えている。このほかに, 通水前にほほ均 質になるように練り混ぜているとはいえ，その中に わずかながら取り込まれている気泡が上昇すること も観察されており，通水中に供試体が均質になって いるとは限らない．水流に曝されている面から下方 へ行くほど供試体の強度が低下していることも考え られるわけである。しかし, 供試体の厚さが $3 \mathrm{~cm}$ と 小さく，通水後調べた供試体内の含水比の鉛直分布 には顕著な変化が現れていなかったことを考えると， 問題はやはり前者ではないかと考えざるを得ない。 いずれにせよ，最初 $10 \mathrm{~min}$.の平均浸食速度を初期浸 食速度と定義するならば，これに関しては十分議論 に耐えうる精度を持つと判断されることから，これ をもって浸食特性を議論していくことにする。

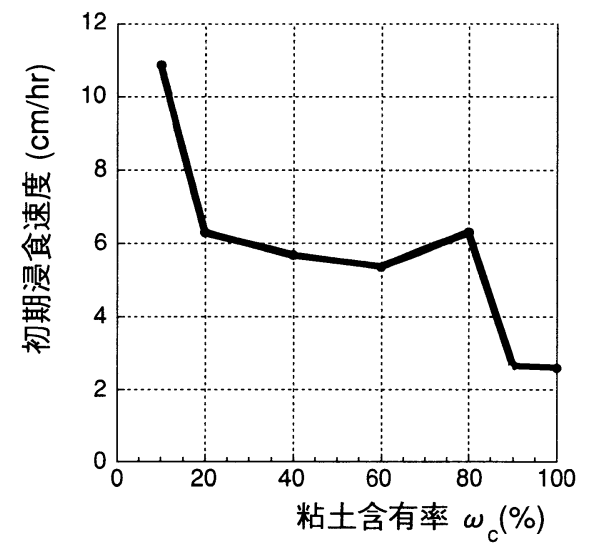

図 - 4 初期浸食速度と粘土含有率との関係： 作用流速 $60 \mathrm{~cm} / \mathrm{sec}$., 水含有率 $50 \%$

そこで, 初期浸食速度と粘土含有率との関係を示し たのが図-4である.この図より次のことがわかる.(1) 供試体に粘土がわずかでも含まれるようになると,浸 食速度が急減し，耐浸食性が急増する。なお，参考ま でに粘土含有率 $0 \%$ (すなわち砂のみ)の場合の浸食速 度を，非粘着性材料に関する Pick-up Rate から試算す ると,その值は $87 \mathrm{~cm} / \mathrm{hr}$. 程度となる. (2) 粘土含有率が $20 \sim 80 \%$ の範囲では浸食速度はほぼ一定值をとる。 また，粘土含有率 $80 \%$ 程度で浸食速度が極大值をと る可能性がある.(3) 粘土だけからなる供試体に $10 \%$ 程度の砂が加わっても浸食速度に大きな変化は見られ ないが,この比率を越えて砂が混入すると浸食速度が 急増し，耐浸食性が急激に低下寸る。このような特性 に関して,あくまで推論に過ぎないとはいえ簡単な考 察を加えておきたい.まず，上記(1)の粘土含有率が20 \%程度までの範囲に関しては, 粘土含有率が増大する に伴い, 骨格となる砂粒子の表面に粘土の皮膜が形成 され，これが粘着力を発揮すると考えられる。そして， このような粘着力の発現が十分に期待できる皮膜が形 


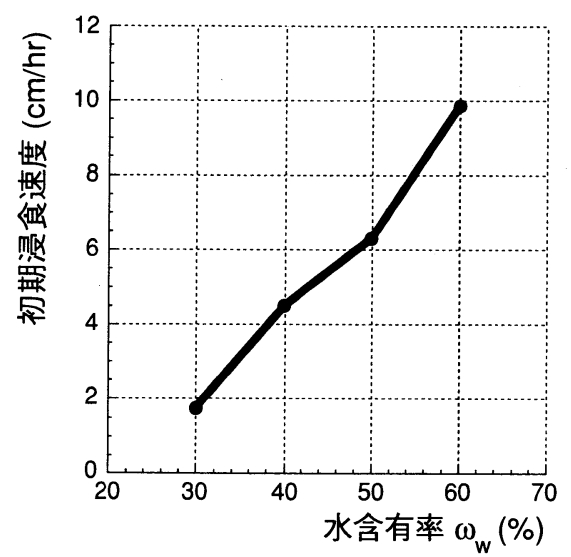

図 -5 初期浸食速度と水含有率との関係： 作用流速 $60 \mathrm{~cm} / \mathrm{sec}$, 粘土含有率 $80 \%$

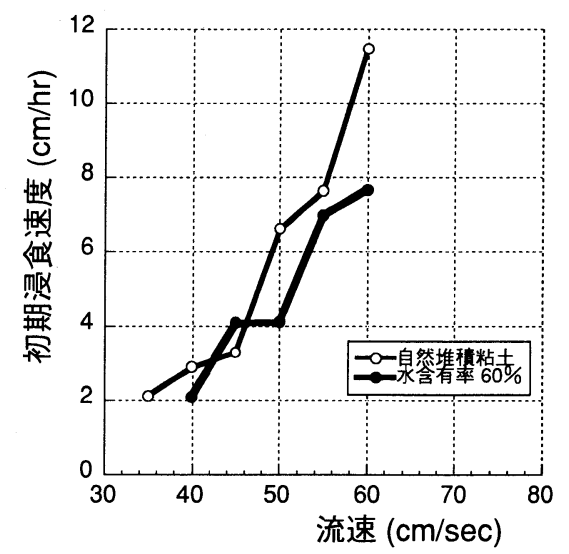

図-6 自然堆積粘土と人工練り混ぜ粘土の 初期浸食速度の比較
成されるのは, 図-4から粘土含有率が $20 \%$ 程度の時 ではないかと推察される。いま, 試みに, 粘土含有率 が $20 \%$ の場合を対象として, 粘土が砂粒子の表面に 均一に付着するとの仮定の下で, 皮膜の厚さを計算 すると $0.05 \mathrm{~mm}$ となり, 粘土の平均粒径の 3 倍(砂の 半径の $6 \%$ )程度に相当していることがわかる.一方, 粘土含有率が $20 \sim 80 \%$ の範囲にあたる(2)について は，木だ検討の最中であり卜分な理解が得られてい ない.ただし，上に説明した $20 \%$ 程度の量を越えて 粘土が存在する場合には，この余分な粘土がコー ティングされた砂の骨格間の空隙を埋め,さらには 砂粒子骨格間の距離を増大させることになるが，上 記の結果は，このような形で存在する粘土が供試体 全体の耐浸食性の向上にはあまり寄与しないことを 意味するものと見ることもできる.また, 粘土含有率 が80〜100\%の範囲にあたる(3)については, 砂粒子 の含有率が $10 \%$ を越え, 供試体内に有意な量の砂が 含まれるようになると, 粘土が面的に粘着力を発揮 しようとするのを砂粒子の存在が妨げる結果となる. そのため, 均質な純粋粘土が発揮すると考えられる 粘着力が十分に発揮されなくなることに加えて, 砂 が供試体表面に露出してくると, そこが弱点箇所と なるために，耐浸食性が急激に低下するものと考え られる。

このような興味深い特徵的な变化パターンは水含 有率が異なる場合にも確認されており, S.A.クレー が持つ特性であることは確かである.

\section{(3) 浸食特性に及ぼす水含有率の影響}

ここでは, 水含有率の変化に伴い生じる浸食特性 の変化について簡単に説明する. 図-5には, 一例と して, 粘土含有率を $80 \%$, 作用流速を $60 \mathrm{~cm} / \mathrm{sec}$. に固 定して, 水含有率の值のみ变化させた場合の測定結 果を示した. なお, 対象とした条件は, 水含有率とし
て定義した重量比が粘土 1 に対して水 $0.3 \sim 0.6$ の範 囲となっている.なお, 当初は, さらに水分量の大き な供試体までを検討対象に考えていたが，この場合 には, 浸食速度がかなり大きくなり,ここで用いた実 験装置では測定精度に問題が生じる恐れがあると予 想されたため，上記の範囲に限ることにした。

さて，図-5を見ると，水含有率が増大するにつれ て初期浸食速度が急增することがわかる，供試体の 状態として, 水含有率が $30 \%$ の場合にはある程度固 く締まった状態にあり，容易に浸食されるようには 見受けられないのに対して, この值が $60 \%$ の場合に は50\%の場合に比べて明らかにルーズになっている。 また, 水含有率が $30 \%$ の場合には, 設定流速下では 溶出形式の浸食しか起こらないのに対して, それ以 上の流速では塊状の剥離形式の浸食が起こることも 確認されている.このことと, 水含有率が $40 \%$ と 50 $\%$ の場合の浸食速度の差が相対的に小さのに対して $50 \%$ と $60 \%$ の間の差ではその差が大きくなってお り，この間で急激に耐浸食性が低下するのでないか と推察される.この点に関しては, 今後さらに広範囲 にわたる実験的検討を行い, 詳細にわたって検証し ていく必要がある.ただし, 少なくとも浸食特性が水 含有率の影響を顕著に受けること, ならびにその傾 向は明らかにできたと考えている.

\section{4. 自然堆積粘土と人工練り混ぜ粘土の比較}

前章までの議論は, あくまで人工的に作成した粘 着性土についてのものであったが, 本研究のような 基礎研究の成果を将来現地の問題に適用していく際 には, 自由沈降により堆積した後に自然圧密を受け た粘性土(こでは自然堆積粘性土と呼ぶ)人工練り 混ぜ粘性土の特性の違いについて調べておくことが 必要である.しかし, 砂と粘土からなる粘着性土を自 
然堆積状態で均質に作成することは容易ではない. そこで,ここでは, 粘土含有率 $100 \%$ の供試体に限定 して, 静水で満たされた水路上方から乾燥状態の粘 土を投入しこれを自然沈降させて作成した均質な自 然堆積粘土と, 前章までに説明してきた人工練り混 ぜ粘土とを対象とした比較実験を行ない，前章まで に検討してきた浸食特性にどのような差が現れるか という点について調べておくことにする.

図-6には, 自然堆積粘土と人工練り混ぜ粘土の初 期浸食速度と作用流速の関係を比較の形で示してい る. 自然堆積粘土の供試体の水含有率を測定したと ころ, 深さ方向にほぼ一定の $60 \%$ 程度の值をとるこ とがわかった，そこで，図-6には，水含有率 $60 \%$ の 人工練り混ぜ粘土のデータを示した. 図-6ならびに 実験時の観察から次のことがわかる.すなわち,(1) 自 然堆積粘土の浸食限界流速は $45 \sim 50 \mathrm{~cm} / \mathrm{sec}$. と判断 され, 練り混ぜ粘土の $50 \sim 60 \mathrm{~cm} / \mathrm{sec}$. 上りも小さな 值となる, (2) 塊状の剥離形式の浸食が生じる流速にお いては, 自然堆積粘土の方が耐浸食性は小さく, 浸食 を受けやすい.これは, 自然堆積粘土の場合に予想さ れる供試体の不均質さに起因するものと考えること ができよう。自然堆積粘土の場合には, 供試体内部の 水含有率は一定であるものの, その密度や空隙率も 均一であるとは言い難い。 そもそも粘土はその粘着 力を電気的な結合力の結果として発揮する. そして, ここで対象とするような浸食を考える上で重要なの は，ある大きさをもった土塊が発揮する粘着力であ る. しかし, 供試体内が不均質で空隙などの弱点とな る箇所が存在する場合には, その部分から浸食が生 じ, 連鎖的に浸食が進むものと考えられる.このよう に, 本研究で用いている人工練り混ぜ粘着性土は, 均 質であるがゆえに自然堆積した粘着性土に比べて耐 浸食性が高いことが理解された。しかし，合わせて浸 食過程自体には定性的に大きな違いがないことも明 らかになった。

\section{5. 結論}

本研究では, 砂と粘土からなる粘着性土の浸食特 性を理解するため，この特性に密接に関わると考え られる「作用流速, 粘土含有率および水含有率」を変 化させた一連の系統的な実験を行った.また, 本研究 で主に用いられている人工練り混ぜ粘性土の特性が, 自然堆積粘性土のものとどの程度異なるかを調べる
ための比較実験を行った。これにより, 粘着性土の浸 食特性が作用流速, 粘土含有率, 水含有率の影響を顕 著に受けることが確認され，その変化特性が定量的 に評価されたほか，そのメカニズムの一端が理解さ れた。

今後は, 残された要因である「供試体の締め固め 度」の影響についての検討を行い, 本研究で用いた S.A.クレーについての更なる理解を深めるとともに, 異なる鉱物組成を持つ粘土についても同様の検討を 進めていくことを計画している.さらに, 現地の自然 堆積粘性土(あるいはへドロ)の浸食特性を検討する手 法についてもあわせて考えていきたい.

謝辞: 本研究の遂行に当たり, 早稲田大学理工学部学 生の白瀬光泰君の精力的な協力を得た。ここに記し て謝意を表します.最後に, 本研究は早稲田大学特定 課題研究助成を受けて行われたことを明記す万。

\section{参考文献}

1) 芦田和男・澤井健二 : 粘土分を含有する砂れき床の侵食 と流砂機構に関する研究, 京都大学防災研究所年報第 17 号 B, pp.571-584, 1974.

2) 芦田和男 ·江頭進治 ·加本 実: 山地流域における侵食 と流路変動に関する研究(1), 京都大学防災研究所年報 第 25 号 B -2, pp.349-361， 1982.

3) 青木美樹 - 首藤信夫 : 粘性土堆皘層の洗掘現象に関する 実験的研究, 第26回水理講演会論文集, pp.87-92,1982.

4) たとえば, 大坪国順: 底泥の飛び出し率の推定, 第 28 回水理講演会論文集, pp.671-677, 1984.

5) 福岡捷二 ・渡邊明英 - 小俣篤 - 片山敏男 - 島本重寿 - 柏 木幸則: 河岸侵食速度に及ぼす土質構造の影響, 水工学 論文集第 42 巻, pp.1021-1026, 1998.

6) 建設省土木研究所河川研究室: 洪水流を受けた時の多自 然型河岸防御工・粘性土・植生の挙動, 土木研究所資料 第 3489 号, 1998.

7) 関根正人, 尾藤文人, 熊谷利彦, 宇野哲平: 粘着性土の 侵食とウオッシュロードとしての土砂の輸送に関する研 究, 土木学会第 53 回年次学術講演会, pp.488-489, 1998. 8) 関根正人, 熊谷利彦, 尾藤文人: 粘着性土の浸食機構に 関する基礎的研究, 水工学論文集第 43 巻, pp.659-664, 1999.

9) 関根正人, 高部一彦 - 飯塚暢明, 熊谷利彦: 粘着性土塊 の浸食特性に及ぼす粘土含有率の影響について, 土木学 会第 54 回年次学術講演会, pp.422-423, 1999.

(1999.9. 30 受付) 